\title{
Immunohistochemistry and Expression Profile of Estrogen Receptor 2 Gene in Different Grade Size Ovarian Follicles of Leizhou Black Ducks
}

Collins Amponsah Asiamah ( $\sim$ kolynsasiamah@gmail.com )

Guangdong Ocean University https://orcid.org/0000-0001-8799-026X

Yuanbo Liu

Guangdong Ocean University

Rungen Ye

Guangdong Ocean University

Yiting Pan

Guangdong Ocean University

Li-li Lu

Guangdong Ocean University

Zhihui Zhao

Guangdong Ocean University

Ying Su

Guangdong Ocean University

Research

Keywords: ovarian follicles, granulosa cells, theca cells, ESR2, Leizhou black ducks

Posted Date: September 14th, 2021

DOl: https://doi.org/10.21203/rs.3.rs-839094/v1

License: (9) (i) This work is licensed under a Creative Commons Attribution 4.0 International License.

Read Full License 
1

3

4 Collins Amponsah Asiamah, ${ }^{*}$ Yuanbo Liu, ${ }^{*}$ Rungen Ye, Yiting Pan, Li-li Lu, Zhihui Zhao, ${ }^{1}$

5

6

7

8

9

10

11

12

13

14

15

16

17

18

19

20

$$
\text { Ying } \mathrm{Su}^{1}
$$

College of Agriculture, Guangdong Ocean University, Zhanjiang, 524025, PR China

\section{* Contributed equally}

1

${ }^{1}$ Correspondence: Ying Su and Zhihui Zhao

Ying Su: dwkxsy@163.com, +8613828218355
Zhao Zhihui: zhzhao@jlu.edu.cn, +8613560503527 


\section{Abstract}

22 Background: Estrogen receptor 2 (ESR2) plays significant biological roles in the reproductive

23 system and ovarian follicle development. This study, therefore, aimed to reveal the expression 24 pattern and cell-specific localization of ESR2 in the ovarian follicles of Leizhou black ducks.

25 Method: Four laying Leizhou black ducks at 43 weeks old were annihilated and different grade-

26 sized follicles were collected for immunohistochemistry and expression profile study. The follicles

27 were grouped into seven (7) as small white follicles (SWF), large white follicles (LWF), small 28 yellow follicles (SYF), large yellow follicles (LYF), follicle 5 (F5), follicle 2 (F2), and follicle 1 $29(\mathrm{~F} 1)$.

Results: The qRT/PCR results displayed that ESR2 mRNA was expressed in all follicles with the 31 highest $(\mathrm{P}<0.05)$ level of expression found in $\mathrm{F} 1$ compared to other follicles. 32 Immunohistochemistry analysis of the cell-specific localization of ESR2 protein revealed that ESR2 was distributed in both granulosa and theca cells region in all the follicles examined. There was a significantly higher localization of ESR2 protein in the granulosa cells than the theca cells of SWF, SYF, LYF, F2, and F1. Comparatively, ESR2 was highly expressed in the granulosa cells of LYF than in all the other follicles.

37 Conclusion: These results provide theoretical knowledge for the in-depth study of the related 38 biological functions of the ESR2 gene and its application at the cellular level.

39 Key words: ovarian follicles, granulosa cells, theca cells, ESR2, Leizhou black ducks. 


\section{Background}

43 Leizhou black duck is an egg-type duck breed known to have excellent egg production and

44 quality traits enriched in nutrients and trace elements (1,2). As a high-quality local duck breed,

45 much research has been done to improve its meat and egg performance and environmental

46 adaptability (2-9).

47 Estrogens belong to the gonadal steroid hormone family synthesized from cholesterol mainly

48 in the ovaries, granulosa cells, and corpora lutea (10,11). Estrogens regulate several biological and

49 physiological functions in the reproductive system $(10,12,13)$ by binding to its cognate receptors;

50 estrogen receptor $1(E S R 1 / E R \alpha / E R 1)$ and estrogen receptor $2(E S R 2 / E R \beta / E R 2)$ which are found

51 in the nuclear receptor superfamily (14-16). The estrogen receptors act as transcription factors to

52 initiate gene transcription through estrogen response elements (EREs) in the target tissues and also

53 interact with other transcription factors (17).

54 The female reproductive organ, the ovary produces and releases eggs and serves as an endocrine

55 gland that produces and discharges hormones $(18,19)$. The ovary also mediates ovulation and

56 provides proteins and steroid hormones for estrous cycle maintenance, secondary sex

57 characteristics, and prepare the uterus for implantation (20-22). The functional unit of the ovary

58 is the ovarian follicles which contain three different types of cells; oocytes, granulosa cells, and

59 theca cells. The oocytes (germ cells) which may form an embryo are surrounded by and form

60 intracellular connections with granulosa cells (somatic cells) which are also surrounded by and

61 form connections with the theca cells (somatic cells) (Figure 1) (20,23-25).

62 Ovarian follicles go through several stages of development throughout the stroma of the cortex

63 from primordial, primary, secondary to preovulatory follicles $(26,27)$. Primordial follicles are

64 inactive with oocytes arrested in the first meiotic prophase in the early postnatal period with 
65 flattened granulosa cells. When primordial follicles become activated, the oocyte grows and 66 granulosa cells differentiate from a flattened appearance to a more cuboidal form and proliferate 67 into primary follicles. As the primary follicle grows, they are surrounded by several granulosa cell 68 layers and recruited theca cells from the interstitial stromal cells on the basement membrane to 69 form Secondary or Pre-antral follicles (28-32). Finally, fluid-filled vesicles emerge in the 70 granulosa cells to form early antral follicles which later amalgamate to form a single large fluid71 filled antral follicle. The proliferation of granulosa cells slows down and the last stage of follicular 72 growth is primarily due to the increase of antral follicles to form preovulatory or Graafian follicles 73 (Figure 1). Granulosa cells differentiate into cumulus and mural cells $(20,22,30)$. The 74 hypothalamic, pituitary and gonadal (HPG) axis regulate follicle development and ovulation by 75 synthesizing gonadotropin hormones (follicle-stimulating hormones, FSH and luteinizing 76 hormone, LH) which coordinate to stimulate the synthesis and discharge of estrogen and 77 progesterone in the somatic cells whose increase may have positive feedback on the HPG axis and 78 gonadotropin hormones to coordinate the development, maturation, and oviposition of follicles 79 (Figure 2) (24,33-38).

80 Generally, the follicles can be categorized into two based on their sizes during development as 81 prehierarchical and hierarchical or preovulatory follicles. Prehierarchical follicles are divided into 82 small white follicles (SWF), large white follicles (LWF), small yellow follicles (SYF), and large 83 yellow follicles (LYF). The hierarchical follicles are also divided from large to small as F1, F2, 84 F3, F4, and F5/6 (Figure 3). After F1 maturation and ovulation, F2 and F3 respectively become 85 new F1 and F2 whereas LYF becomes preovulatory follicles $(33,39,40)$. The ovarian follicle 86 development in poultry is dependent on the efficient differentiation and proliferation of the 
87 granulosa and theca cell layers to enhance prehierarchical follicles to mature into hierarchical 88 follicles. $(39,41,42)$.

89 Therefore, this study elucidated the expression profile of ESR2 in the different grade-sized 90 follicles and the localization of ESR2 protein in the granulosa and theca cells of the follicles.

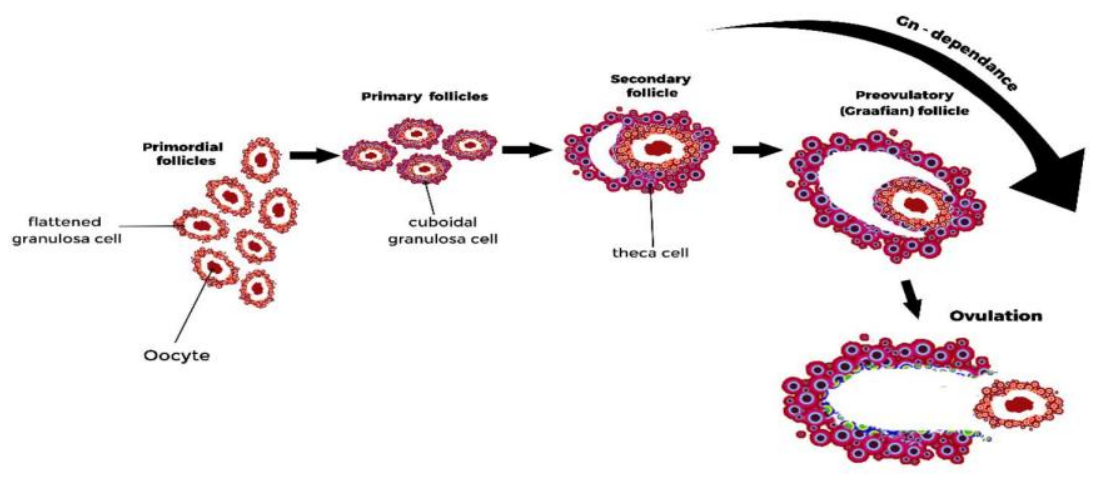

92 Figure 1. Ovarian follicle development in poultry. Primordial follicles become activated, the 93 oocyte grows and granulosa cells differentiate from a flattened appearance to a more cuboidal form 94 and proliferate to form primary follicles. Primary follicles grow and are surrounded by several 95 granulosa cell layers and recruited theca cells into Secondary follicles. The proliferation of 96 granulosa cells slows down and the last stage of follicular growth is primarily due to the increase 97 of secondary follicles to form preovulatory or Graafian follicles. Gn, gonadotropin. 


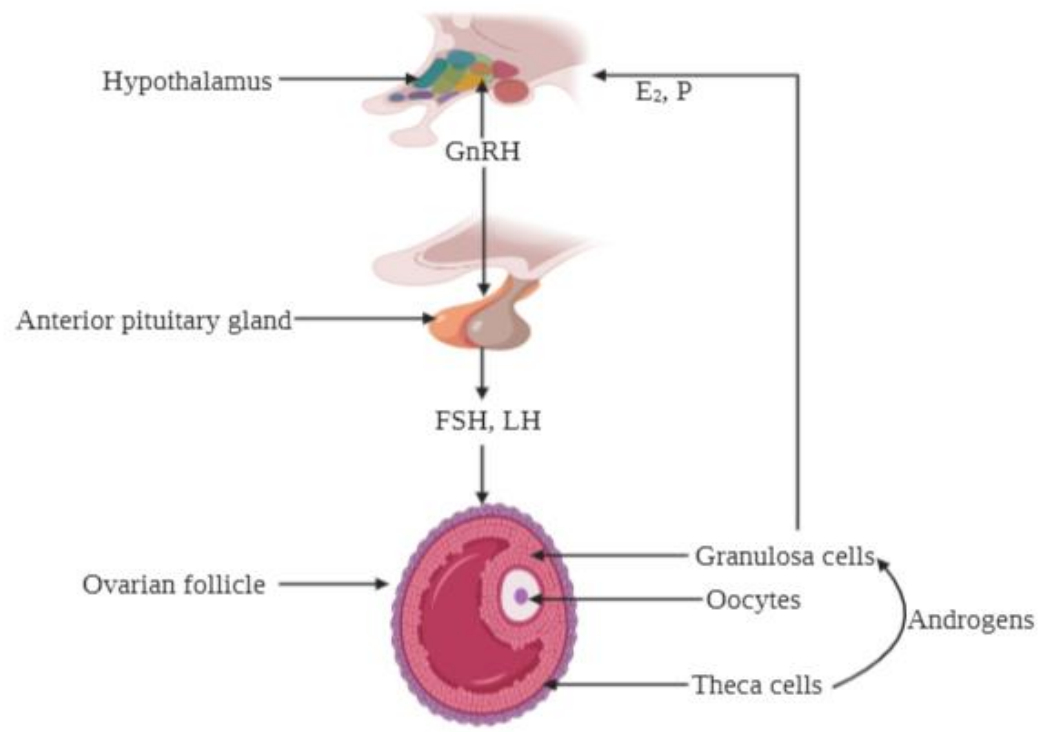

99 Figure 2. Hormonal regulation of ovarian follicle development. GnRH is discharged from the hypothalamus into the portal circulation to operate on the gonadotrope cells in the anterior pituitary

101 gland to excite the synthesis and discharge of FSH and LH. FSH and LH enhance the synthesis 102 and discharge of estrogen and progesterone in granulosa and theca cells whose increase may have 103 positive feedback on the HPG axis and gonadotropin hormones to coordinate the development, 104 maturation, and oviposition of follicles. Androgens from theca cells are aromatized to $E_{2}$ in the 105 granulosa cells. GnRH, gonadotropin-releasing hormone; FSH, follicle-stimulating hormone; LH, 106 luteinizing hormone; $\mathrm{E}_{2}$, estradiol (estrogen); $\mathrm{P}$, progesterone. Arrows indicate positive 107 stimulatory effects. 


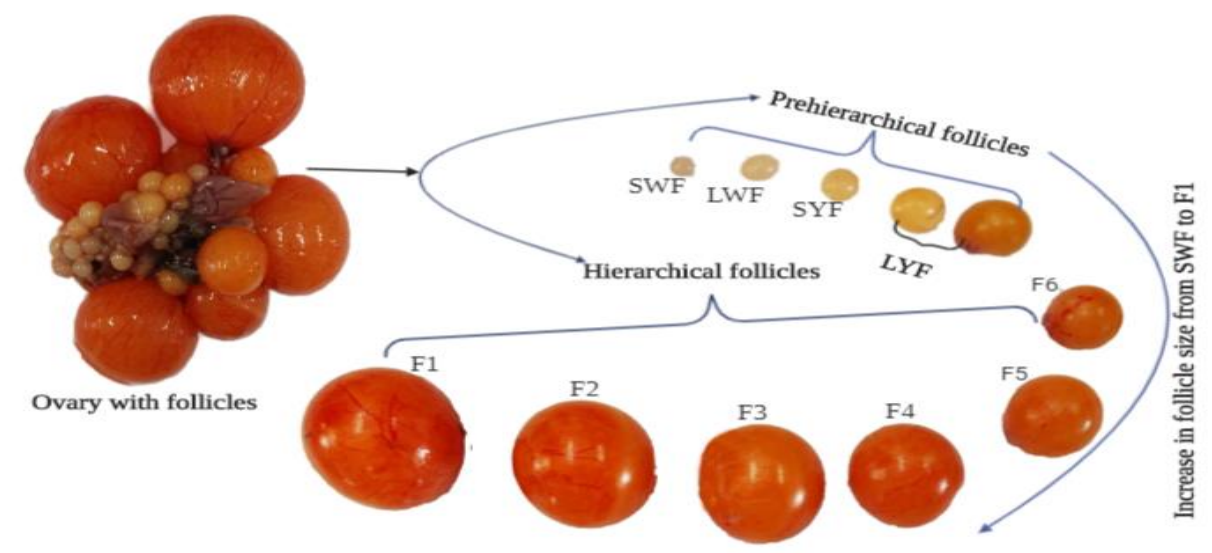

Figure 3. Diagram of Leizhou black duck ovary and ovarian follicles showing numerous rounded and different grade size follicles. The follicles are divided into two categories; prehierarchical and hierarchical follicles. F1-F6, follicles 1-6; LYF, large yellow follicles; SYF, small yellow follicles; LWF, large white follicles, and SWF, small white follicles.

\section{Materials and methods}

\section{Animals and sample collection}

115 All the animals were maintained and studied following the National Institute of Health (NIH) 116 guidelines for care and use of laboratory animals, and all protocols were approved in advance by 117 the Animal Care and Ethics Committee of Guangdong Ocean University of China (No. 118 NXY20160172).

Four (4) female Leizhou black ducks at 43 weeks of laying were used in this study. Follicles at different growth stages were collected from laying Leizhou black ducks based on their diameter 121 according to the "Poultry Entity Anatomy Atlas" (43), Leizhou black duck follicles were grouped 122 as; SWF: <4 mm, LWF: 4.49 $\pm 0.43 \mathrm{~mm}$, SYF: $5.81 \pm 0.37 \mathrm{~mm}$, LYF: $6.94 \pm 0.29 \mathrm{~mm}$, F6: $12310.63 \pm 0.88 \mathrm{~mm}, \mathrm{~F} 5: 14.11 \pm 0.61 \mathrm{~mm}, \mathrm{~F} 4: 17.33 \pm 1.13 \mathrm{~mm}, \mathrm{~F} 3: 24.31 \pm 1.24 \mathrm{~mm}, \mathrm{~F} 2: 30.70 \pm 1.42$ mm, F1: 34.34 $\pm 0.44 \mathrm{~mm}$. In this study, however, we selected SWF, LWF, SYF, LYF, F5, F2, and 
125 F1. All follicular tissues were quickly collected into tubes containing liquid nitrogen and stored in 126 a refrigerator at $-80^{\circ} \mathrm{C}$ for later use. Again, samples of all the follicle tissues were collected and 127 quickly fixed into formalin and stored at room temperature for immunohistochemistry studies. Egg 128 yolk in bigger grade-sized follicles (LYF, F5, F2, and F1) were rinsed and washed in PBS and 129 quickly fixed in the formalin while smaller follicles (SWF, LWF, and SYF) were directly fixed 130 into the formalin.

\section{RNA extraction and reverse transcription}

132 Total RNA was extracted from each tissue using Magzol reagent (Beijing, Quanshijin), following 133 the manufacturer's protocol. The quality and concentrations of the RNA were detected 134 respectively by $1 \%$ agarose gel electrophoresis and NanoDrop 2000 spectrophotometer (Thermo 135 Scientific, Waltham, USA) at 260:280nmratio. Reverse transcription was performed to synthesize 136 cDNA using PrimeScript RT Reagent kit with gDNA Eraser (Beijing, Quanjin) according to the 137 manufacturer's protocol.

\section{Expression profile of the $\boldsymbol{E S R} 2$ gene in Leizhou black duck}

139 According to the ChamQTM SYBR qPCR Master Mix 7750 (Trans, Guangzhou) fluorescence 140 quantification kit, the fluorescence quantification of each sample tissue was performed on the 141 Applied Biosystems StepOnePlus (USA) fluorescence quantitative PCR. All primers were 142 designed using Primer Premier 6.0 (Palo Alto, USA) and synthesized by Sangon Biotechnology

143 (Shanghai, China). The detailed information of all primers used in this study is provided in table 144 1. Three replicates for ESR2 and $\beta$-actin were performed in every tissue. PCR reaction system: $14510 \mu \mathrm{L}$ ChamQTM SYBR qPCR Master Mix, $0.5 \mu \mathrm{L}$ PCR Forward Primer $(0.5 \mu \mathrm{M}), 0.5 \mu \mathrm{L}$ PCR 146 Reverse Primer $(0.5 \mu \mathrm{M}), 0.5 \mu \mathrm{L}$ cDNA, $8.5 \mu \mathrm{L}$ ddH2O, a total volume of $20 \mu \mathrm{L}$ amplification 147 reaction. Reaction procedure to amplify the template was $95^{\circ} \mathrm{C}, 30 \mathrm{~s} ; 40$ cycles $\left(95^{\circ} \mathrm{C}, 10 \mathrm{~s} ; 56^{\circ} \mathrm{C}\right.$, 
$14830 \mathrm{~s}$; lighting; $\left.72^{\circ} \mathrm{C}, 25 \mathrm{~s}\right) ; 95^{\circ} \mathrm{C}, 15 \mathrm{~s} ; 60^{\circ} \mathrm{C}, 1 \mathrm{~min} ; 95^{\circ} \mathrm{C}, 15 \mathrm{~s}$. The relative expression levels of the

149 genes test were calculated using the $2-\Delta \Delta \mathrm{Ct}$ method (44).

150 Table 1. Primer pairs designed for quantitative real-time PCR

\begin{tabular}{lllll}
\hline Gene & Sequence $\left(\mathbf{5}^{\prime} \mathbf{- 3}^{\prime} \mathbf{)}\right.$ & $\begin{array}{l}\text { Product } \\
\text { length }(\mathbf{b p})\end{array}$ & $\begin{array}{l}\text { Annealing } \\
\text { temperature }\left({ }^{\circ} \mathbf{C}\right)\end{array}$ & \\
& & & Login ID \\
\hline ESR2 & F: CAGTGCTACCTGTGACCAGA & 168 & 60.0 & XM_021274553.2 \\
& R: TGCAGCCTTCACATGACCAG & & & \\
B-actin & F: CGCAAATGCTTCTAAACC & 167 & 55.9 & NM_001310421.1 \\
& R: AGACTGCTGCTGATACCTT & & & \\
\hline
\end{tabular}

151

152 Immunohistochemistry of ESR2 gene in ovarian follicles

153 Immunohistochemistry (IHC) for ESR2 was performed according to Wuhan servicebio technology

154 CO., LTD standard operating procedures.

155 Freshly dissected follicular tissues (less than $3 \mathrm{~mm}$ thick) were fixed in $4 \%$ paraformaldehyde

156 (Servicebio, G1101) for 24 hours at room temperature. The sections were then sequentially

157 deparaffinized with xylene (Sinopharm Chemical Reagent Co., Ltd.) and rehydrated. Antigen

158 retrieval was performed with EDTA (PH9.0) antigen retrieval solution (Servicebio, G1203) in a

159 microwave oven at medium heat for 8 minutes and after cooling, the slides were washed 3 times,

1605 minutes each in PBS (PH7.4). To block endogenous peroxidase, the slides were put in 3\%

161 hydrogen peroxide solution (Servicebio, G0115), incubated at room temperature for $25 \mathrm{~min}$ in the

162 dark, and washed 3 times, 5 minutes each in PBS (PH7.4). The slides were incubated with 3\%

163 BSA solution (Servicebio, G5001) to block for 30 minutes at room temperature. Sections were 
164 incubated overnight at $4^{\circ} \mathrm{C}$ with primary mouse ESR2 ab288 antibodies diluted with PBS followed

165 by washing with PBS (PH7.4) 3 times for 5 minutes each. After the sections were dried slightly,

166 they were incubated in the HRP mouse secondary antibody at room temperature for 50 minutes.

167 After 3 washes with PBS (PH7.4) for 5 minutes each, the sections were incubated for 30 min in 168 diaminobenzidine (DAB) staining solution (Servicebio, G1211) with $30 \% \mathrm{H}_{2} \mathrm{O}_{2}$ and then 169 counterstained with hematoxylin for 3 minutes (Servicebio, G1340) and differentiated with 170 hematoxylin differentiation solution (Servicebio, G1309) for a few seconds. The sections were 171 dehydrated with graded series of alcohol, ethanol, and xylene and then dried slightly and mounted 172 on a microscope (CIC, XSP-C204) with neutral gum (Servicebio, G1403).

173 Results

174 Expression profile of ESR2 gene in different grade-sized follicles of laying Leizhou black 175 ducks

176 To evaluate the expression pattern of ESR2 in the follicles of laying Leizhou black ducks, seven 177 (7) different grade-sized follicles were selected from the ducks and detected by RT-qPCR. The 178 results showed that ESR2 was expressed in all tissues (Figure 4). The highest expression level of 179 ESR2 was found in F1 compared to other tissues followed by F2, F5, and LYF. Obvious ESR2 180 mRNA expression was discovered in SWF and LWF with lower expression levels in SYF. ESR2

181 gene was significantly $(\mathrm{P}<0.01)$ expressed in $\mathrm{F} 1$ compared to the other grade-sized follicles 182 except for F2 (Figure 4). ESR2 expression was not significantly (P > 0.05) different in F2, F5, and 183 LYF. There was a significant $(\mathrm{P}<0.01)$ difference in the expression of ESR2 in F2 and F5 184 compared to SWF, LWF, and SYF. The expression of ESR2 was not significantly $(\mathrm{P}>0.05)$ 185 different in SWF, LWF, SYF, and LYF. 


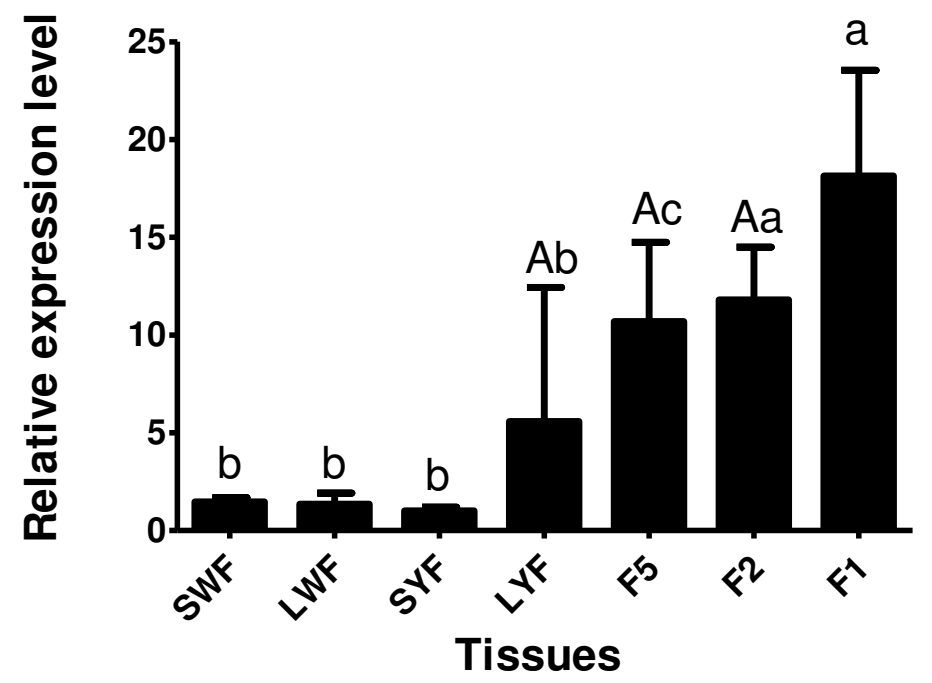

Figure 4. Expression pattern of ESR2 in different grade-sized follicles of laying Leizhou black ducks.

NB: SWF- small white follicles; LWF-large white follicles; SYF- small yellow follicles; LYFlarge yellow follicles; F5- follicle 5; F2- follicle 2; F1-follicle 1; GC- granulosa cells; TC- theca cells. Different lower and upper cases show a significant difference $(P<0.01 ; 0.05)$.

\section{Localization of $E S R 2$ in the ovarian follicular cells}

In situ localization results indicated the intense and specific signals in the granulosa and theca

194 cells. The staining and the proportion of positive cells varied between the different cell types

195 (Figure 5). The nucleus stained with hematoxylin is blue, and the positive expression of DAB is 196 brown. The presence of ESR2 mRNA, identified by brown cytoplasmic staining was found in all 197 the follicular stages in both cells. Generally, the ESR2 protein was highly localized in the granulosa 198 region than in the theca region (Figure 6C). In LYF and F1, the ESR2 protein was extremely and 199 significantly $(\mathrm{P}<0.01)$ localized in the granulosa region than the theca region. Also, the ESR2 protein was significantly $(\mathrm{P}<0.05)$ localized in the granulosa region than the theca region in SWF, 
201 SYF, and F5. Even though, the expression of ESR2 was higher in the granulosa region than the 202 theca region in LWF and F5, the difference was not significant $(\mathrm{P}>0.05)$.

203 The localization of ESR2 protein in granulosa cells was highest in LYF followed by F1, F2, 204 SWF, F5, SYF, with the lowest expression in LWF (Figure 6A). Expression pattern of ESR2 in the 205 granulosa cells across the different grade-sized follicles revealed that ESR2 protein expression was 206 significantly $(\mathrm{P}<0.01 ; 0.05$ respectively) higher in LYF granulosa cells than LWF and SYF 207 granulosa cells. There was no significant $(\mathrm{P}>0.05)$ difference in the localization of ESR2 protein 208 in LYF, F1, F2, F5, and SYF granulosa cells (Figure 6A).

209 The localization of ESR2 protein in theca cells was highest in F1 followed by F2, LYF, F5, 210 SYF, SWF, with the lowest expression in LWF (Figure 6B). The expression pattern of ESR2 in 211 the theca cells across the different grade-sized follicles revealed that ESR2 protein expression in 212 F1, F2, and LYF was significantly $(\mathrm{P}<0.01)$ higher than LWF. There was no significant $(\mathrm{P}>$ 213 0.05) difference in the localization of ESR2 protein in F1, F2, LYF, F5, SYF, and SWF theca cells 214 (Figure 6B). 

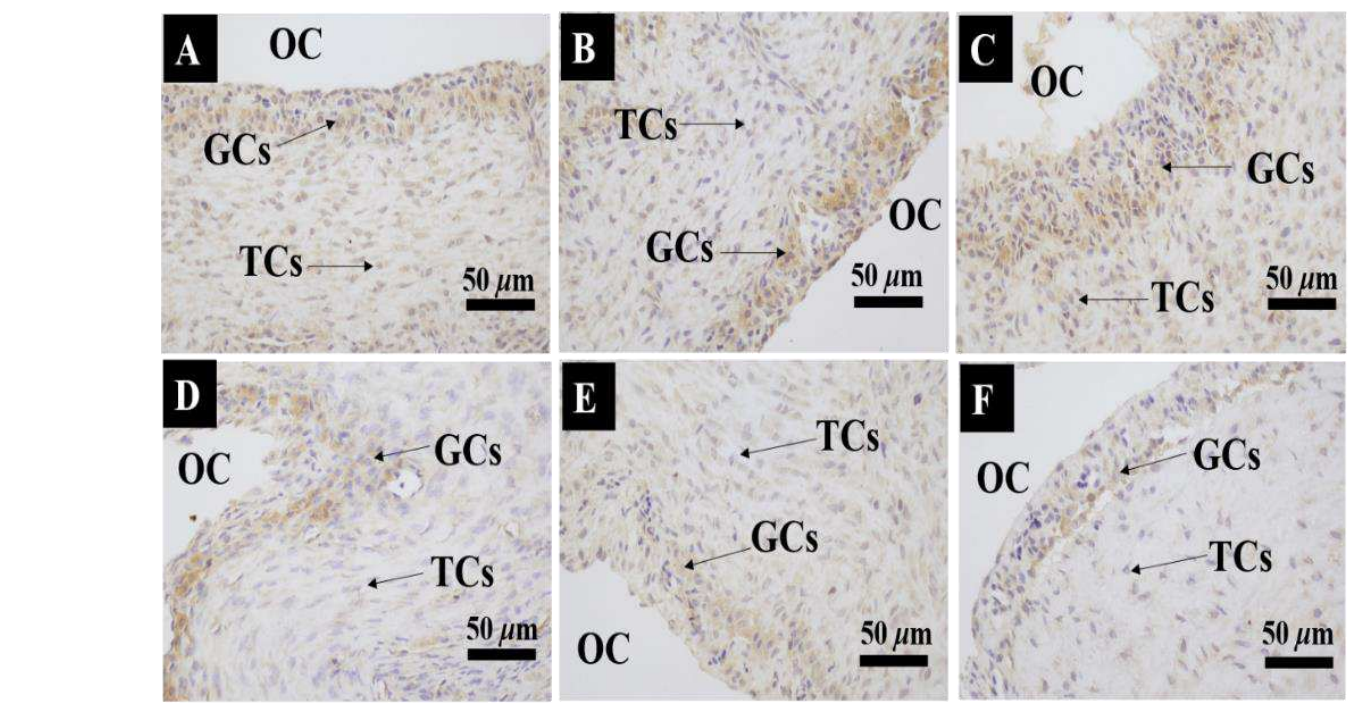

F

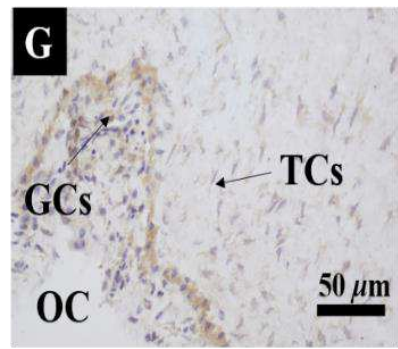

Figure 5. Representative immunolocalization of ESR2 proteins (brown) in Leizhou black

217 duck ovarian follicles. Paraformaldehyde-fixed tissue sections were immunostained using anti218 mouse ESR2. Panels A to G, showing strong immunostaining were observed in all granulosa cells 219 (GCs) within the various-sized ovarian follicles sampled. The scale bar is $50 \mu \mathrm{m}$.

220 NB: A- small white follicles; B-large white follicles; C- small yellow follicles; D- large yellow 221 follicles; E- follicle 5; F- follicle 2; G-follicle 1; GCs- granulosa cells; TCs- theca cells; OC- oocyte 

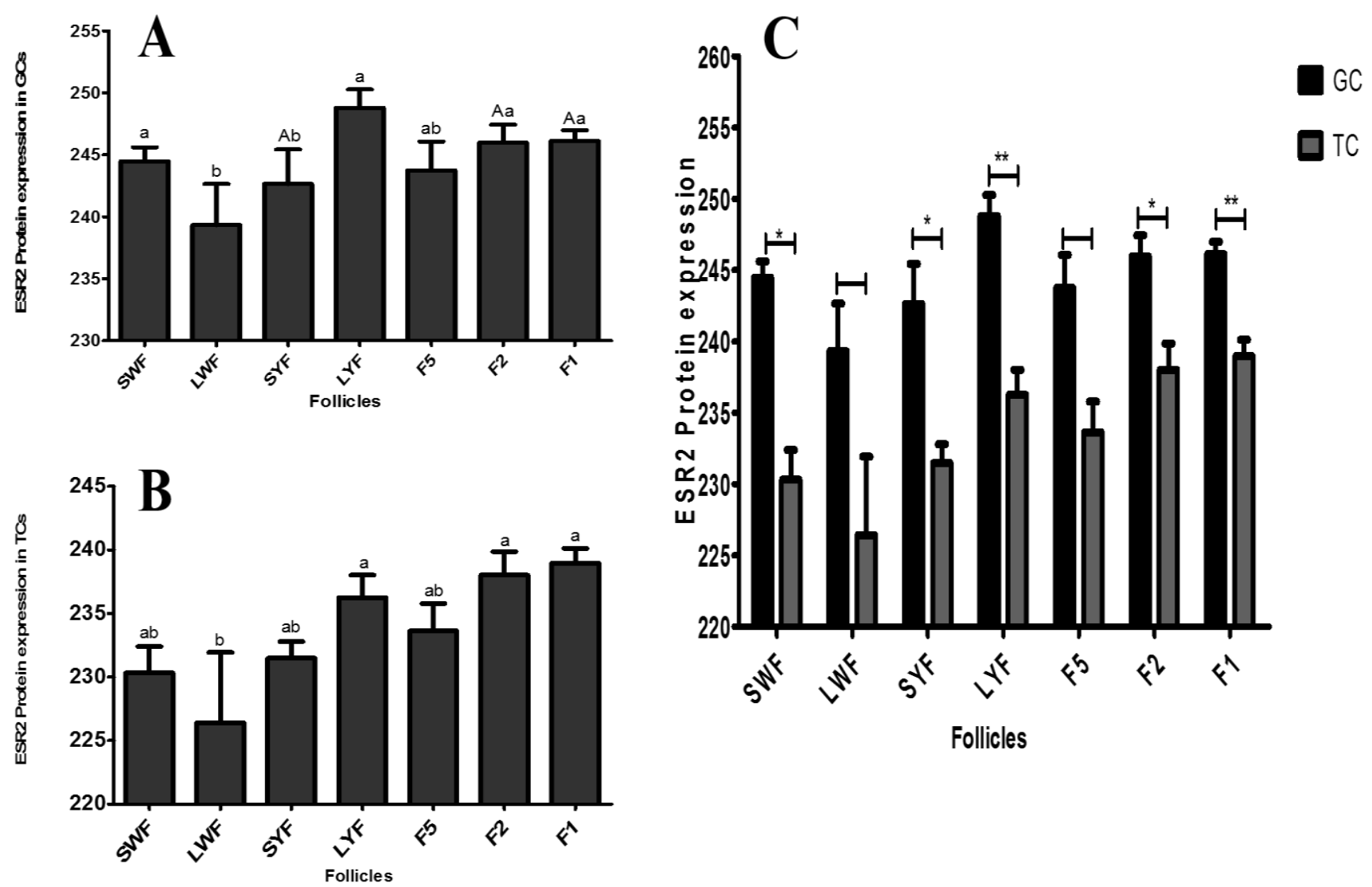

223 Figure 6. The localization of ESR2 protein in GCs and TCs of different grade-sized follicles

224 NB: SWF- small white follicles; LWF-large white follicles; SYF- small yellow follicles; LYF-

225 large yellow follicles; F5- follicle 5; F2- follicle 2; F1-follicle 1; GC-granulosa cells; TC- theca 226 cells. * signifies a significant difference $(\mathbf{P}<0.05), * *$ signifies a significant difference $(\mathbf{P}<$ 227 0.01). Different lower and upper cases show a significant difference $(P<0.01 ; 0.05)$. 


\section{Discussion}

233

234

235

236

237

238

239

240

241

242

243

244

245

246

247

\section{Expression profile of $E S R 2$ gene in different grade-sized follicles of laying Leizhou black}

\section{ducks}

The ovarian follicles are the functional unit of the ovary which contains three different types of cells; oocytes, granulosa cells, and theca cells. The poultry follicles can be categorized as prehierarchical and hierarchical follicles. Prehierarchical follicles are divided into SWF, LWF, SYF, and LYF whilst the hierarchical follicles are divided from large to small as F1, F2, F3, F4, F5/6. As the granulosa and theca layers proliferate and differentiate, the prehierarchical follicles mature into hierarchical follicles $(39,41,42)$. FSH and LH promote the production of estrogen (estradiol) by the granulosa cells to enhance the development of the ovarian follicles (22).

Given this, we selected four prehierarchical (SWF, LWF, SYF, and LYF) and three hierarchical (F1, F3, and F5) follicles to detect the expression pattern of ESR2 in the different grade sized follicles. After qPCR analysis, the results showed that ESR2 was expressed in all the grade-sized follicles with the highest expression in F1, F3, F5, LYF, LWF, SWF, and SYF respectively. Generally, ESR2 mRNA increased as the follicle size increased, thus, the higher the follicles, the higher the ESR2 mRNA.

Preovulatory/Graafian follicles are a major source of estrogen because the dominant selected follicle has an aromatase activity that is more sensitive to FSH than the other smaller follicles. Thus the dominant follicle is capable of producing larger amounts of estrogen than the smaller follicles $(45,46)$ which may be the cause of higher ESR2 expression in hierarchical follicles than the prehierarchical follicles in this study. Similar to our findings, a study in the chicken ovary revealed that ESR2 was highly expressed in white follicles followed by yellow follicles and small 
254 yellow follicles (47). The expression of ESR2 mRNA was examined in prehierarchical (white and

255 yellow follicles) after treating Hy-Line hens with recombinant chicken GH. The study revealed

256 that ESR2 mRNA increased progressively in white follicles from 14 weeks to 17 weeks whereas,

257 in yellow follicles, it decreased on the 17th week (48). A recent study that investigated the secretion

258 of the reproductive hormone during follicle development in Yangzhou, Carlos, and Zhejiang geese

259 revealed that estradiol $\left(\mathrm{E}_{2}\right)$ concentration at LWF to SYF stages was highest in Zhejiang than the

260 other two breeds. However, there was no significant difference in $\mathrm{E}_{2}$ concentration in hierarchical

261 follicles in all three breeds. This signifies that $\mathrm{E}_{2}$ plays a vital role in follicle development from

262 the prehierarchichal form into hierarchical forms (39). There was a higher expression of ESR in

263 all the follicles examined with increasing photoperiods which greatly improved the reproductive

264 organ and follicle development in layer ducks at the pullet phase (33).

265

Localization of ESR2 in the granulosa and theca cells of the ovarian follicles

266 Both granulosa and theca cells synthesize several hormones to promote and regulate follicle

267 maturation and development $(24,30)$. FSH and LH work in the plasma membranes of granulosa

268 and theca cells respectively to promote the synthesis and discharge of estrogen and progesterone

269 respectively $(24,33,39,49,50)$. Androgens produced by the theca cells are taken and up by the

270 granulosa cells and converted by P450 aromatase into estrogen (51). Thus, this study considered

271 the localization of ESR2 in the two cells due to their proximity in functions for follicle growth and

272 development in seven different grade-sized follicles.

273 The findings of this study showed the cell-specific localization of ESR2 in the follicles of

274 Leizhou black ducks. ESR2 protein was more pronounced and localized in the granulosa cells than

275 theca cells of all the different grade-sized follicles in this study. Similarly, a study in chicken pre-

276 ovulatory follicles (F3, F2, and F1) revealed that ESR2 was significantly expressed in the granulosa 
277 cells than theca cells of F3 and F2 follicles. However, the vice-versa was the case for F1 follicles

278 (47). Again, during the gonadal development of Tammar wallaby, the ontogeny of ERs revealed 279 that ESR2was found in both GC and TC of follicles at all stages of development where ESR2 was 280 highly cytoplasmic in GC with weak staining in TC (52).

which is consistent with an earlier study in the ovaries of humans and marmosets where ESR2 was expressed in the granulosa cells of all follicle stages examined (53). Another study in bovine revealed a moderate to high $E S R 2$ expression in the follicle cells of primordial and primary follicles which were higher than in secondary follicle cells. The granulosa cells showed higher expression of ESR2 in tertiary follicles than that in the secondary follicle cells (46). In humans (54), cattle

287 (55), and rats (56), there was a high expression of ESR2 in the granulosa cells of pre-antral and antral follicles which same was revealed in this study. Contrary to the findings of this study, there was a highly specific expression of ESR2 in the GC layer of small and developing follicles that declined with increasing follicle size (57). Regardless of the follicle-specific expression differences between different species, our findings and previous ones show that estrogens are involved in folliculogenesis by interacting with ESR2.

Findings in this study revealed that the highest expression of ESR2 was found in the GC of LYF which is necessary for follicular development and selection into the hierarchical follicle. In poultry, 295 after the ovary has matured, the ovulation procedure is strictly based on hierarchical order (F6F1). After F1 ovulation, a follicle is selected from LYF to replace F6 and the yolk material in the 297 selected LYF follicle is quickly deposited for grade follicular development (58). LYF is an important reserve follicle that develops into grade follicles and its development and recruitment 
LYF have a high probability of entering the grade follicular stage $(40,60,61)$. Therefore, ESR2 was localized in SWF, LWF, SYF, and LYF to enhance their growth and development for recruitment and selection into the hierarchical order in Leizhou black duck.

Pre-ovulatory follicles are a major source of estrogen because the dominant selected follicle has an aromatase activity that is more sensitive to FSH than the other smaller follicles. Thus the dominant follicle is capable of producing larger amounts of estrogen than the smaller follicles $(45,46)$. Affirmatively, in this study, ESR2 was high in all the cells of the pre-ovulatory follicles (F5, F2, and F1) to bind to the large amounts of estrogen to enhance its activity in the follicles for growth, oocyte maturation, and ovulation in Leizhou black ducks.

\section{Conclusion}

ESR2 mRNA was expressed in all follicles with the highest expression level found in F1. Immunohistochemistry analysis of the cell-specific localization of ESR2 protein revealed that ESR2 was distributed in both granulosa and theca cells region in all the follicles examined. ESR2 protein was highly localized in the granulosa cells than the theca cells in all the follicles. Comparatively, ESR2 was highly expressed in the granulosa cells of LYF than in all the other follicles. These results provide theoretical knowledge for the in-depth study of the related biological functions of the ESR2 gene and its application at the cellular level.

\section{Abbreviations}

ESR2: Estrogen receptor 2; GC: granulosa cell; TC: theca cell; OC: oocyte; LYF: large yellow follicles; SYF: small yellow follicles; LWF: large white follicles; and SWF: small white follicles. 


\section{Acknowledgment}

322 The authors gratefully acknowledge the funders, Jiang Ping, Lu Huixian and all professors and 323 students in the Animal science department.

324 Authors' contribution

325 CAA: Conceptualization, design, experimentation, data curation and analysis, writing-original 326 draft; writing-review \& editing. YL: Experimentation, methodology, data curation and analysis, 327 software. RY: Experimentation and data curation. YP: Experimentation and data curation. LL: 328 Experimentation, methodology, data curation and analysis, software. YS: Conceptualization, 329 funding acquisition, methodology, project administration; supervision; writing-review \& editing. 330 ZZ: Funding acquisition, project administration, supervision; Writing-review \& editing. All 331 authors read and approved the final manuscript.

\section{$332 \quad$ Funding}

333 This study was funded by Guangdong Science and Technology Plan Project (2017A020208066) 334 and Provincial-level major scientific research project in Guangdong Province (2017KZDXM043).

335 Availability of data and materials

336 All data generated or analyzed during this study are included in this published article.

\section{Declarations}

\section{Ethics approval and consent to participate}

339 All the animals were maintained and studied following the National Institute of Health (NIH) 340 guidelines for care and use of laboratory animals, and all protocols were approved in advance by 
341 the Animal Care and Ethics Committee of Guangdong Ocean University of China (No.

342 NXY20160172).

343 Consent for publication

344 Not applicable.

345 Competing Interest

346 The authors declare that they have no competing interests.

$347 \quad$ References

348 1. Huang J, Su Y, Liao Y, Wang H, Chen Q, Ma M, et al. Observation on behavioral 349 characteristics of Leizhou black duck on tidal flats. J South Agric. 2014;45(3):484-8.

350 2. Lu L, Xue Y, Asiamah CA, Zou K, Liu Y, Su Y. Evaluation of egg-laying performance, 351 egg quality traits, and nutritional values of eggs of leizhou black duck. Eur Poult Sci. $352 \quad 2020 ; 84: 1-16$.

353 3. Tang Q, Su Y, Zhang L, Liu L, Chen Q, Meng M, et al. Clone and protein function analysis 354 of p94 partial sequence of Leizhou black duck. Guangdong Agric Sci. 2013;1:147-53.

355 4. Meng M, Tang Q, Su Y, Chen Q, Zhang H. Determination of slaughter performance and 356 meat quality in different sex of Leizhou black ducks. Chinese J Anim Husb Vet Med. $357 \quad 2013 ; 40(9): 124-7$.

358 5. Meng M, Su Y, Tang Q, Chen Q, Huang J, Liu H. Canonical correlation analysis between 359 body measurements and slaughter performance in Leizhou Black Ducks. Chinese Agric Sci 360 Bull. 2014;30(5):33-7.

361 6. Meng M, Su Y, Wang H, Tang Q, Chen Q, Huang J, et al. Study on the quality of Leizhou 
black duck egg. Jiangsu Agric Sci. 2014;42(2):159-61.

363 7. Asiamah C, Xue Y, Lu L-L, Zou K, Zhao Z, Su Y. Evaluation of growth performance on 364 family breeding of the Leizhou Black Duck: A preliminary study. Vet Med Sci. 2020;

365 8. Zou K, Huang JT, Nawab A, Lu LL, Cui HY, Zhang SW, et al. Association of 366 LOC101800257 gene with eggshell color in Leizhou black duck. Thai J Vet Med. $367 \quad 2019 ; 49(2): 147-54$.

368 9. Zou K, Asiamah CA, Lu L li, Liu Y, Pan Y, Chen T, et al. Ovarian transcriptomic analysis 369 and follicular development of Leizhou black duck. Poult Sci. 2020;99(11):6173-87.

370

371

10. Fuentes N, Silveyra P. Estrogen receptor signaling mechanisms. Intracell Signal Proteins [Internet]. $\quad 1$ st $\quad$ ed. 2019;116:135-70. Available from: http://dx.doi.org/10.1016/bs.apcsb.2019.01.001

373 11. Knapczyk-Stwora K, Duda M, Grzesiak M, Galas J, Koziorowski M, Slomczynska M. 374 Expression of estrogen receptor at (ER alpha) and estrogen receptor beta (ER beta) in the 375 376 ovarian follicles and corpora lutea of pregnant swine. Domest Anim Endocrinol. 2008;35(2):170-9.

12. Hamilton KJ, Arao Y, Korach KS. Estrogen hormone physiology: Reproductive findings from estrogen receptor mutant mice. Reprod Biol [Internet]. 2014;14(1):3-8. Available from: http://dx.doi.org/10.1016/j.repbio.2013.12.002

13. Nelson ER, Habibi HR. Estrogen receptor function and regulation in fish and other vertebrates. Gen Comp Endocrinol [Internet]. 2013;192:15-24. Available from: http://dx.doi.org/10.1016/j.ygcen.2013.03.032 
383 14. Chen C, Gong X, Yang X, Shang X, Du Q, Liao Q, et al. The roles of estrogen and estrogen receptors in gastrointestinal disease (Review). Oncol Lett. 2019;18(6):5673-80.

385 15. Murphy LC, Dotzlaw H, Leygue E, Coutts A, Watson P. The pathophysiological role of 386 estrogen receptor variants in human breast cancer. J Steroid Biochem Mol Biol. 1998;65(1-

16. Okat Z. Molecular dynamics of estrogen receptors. Eurasian J Med Oncol. 2018;2(41):189_ 97.

17. Hall JM, McDonnel DP. The estrogen receptor $\beta$-isoform $(\mathrm{ER} \beta)$ of the human estrogen 391 receptor modulates $\mathrm{ER} \alpha$ transcriptional activity and is a key regulator of the cellular response to estrogens and antiestrogens. Endocrinology. 1999;140(12):5566-78.

18. Zhu ZM, Miao ZW, Chen HP, Xin QW, Li L, Lin RL, et al. Ovarian transcriptomic analysis of Shan Ma ducks at peak and late stages of egg production. Asian-Australasian J Anim Sci. 2017;30(9):1215-24.

19. Asiamah Amponsah C, Zou K, Lu L li, Zhang SW, Xue Y, Su Y, et al. Genetic effects of 397 polymorphisms of candidate genes associated with ovary development and egg production traits in ducks. Anim Reprod Sci. 2019;211(October):1-9.

20. Luderer U. Ovarian Toxicity from Reactive Oxygen Species. Vitam Horm [Internet]. 1st ed. 2014;94:99-127. Available from: http://dx.doi.org/10.1016/B978-0-12-8000953.00004-3

402 21. Pan L, Gong W, Zhou Y, Li X, Yu J, Hu S. A comprehensive transcriptomic analysis of 403 infant and adult mouse ovary. Genomics, Proteomics Bioinforma. 2014;12(5):239-48. 
404 22. Shimizu T. Molecular and cellular mechanisms for the regulation of ovarian follicular 405 function in cows. J Reprod Dev. 2016;62(4):323-9.

406 23. Findlay J, Kerr J, Britt K, Liew S, Simpson E, Rosairo D, et al. Ovarian physiology: follicle 407 development, oocyte and hormone relationships. Anim Reprod. 2009;6(1):16-9.

408 24. Zhu G, Fang C, Li J, Mo C, Wang Y, Li J. Transcriptomic diversification of granulosa cells 409 during follicular development in chicken. Sci Rep [Internet]. 2019;9(1):1-16. Available 410 from: http://dx.doi.org/10.1038/s41598-019-41132-1

411 25. Charlier C, Montfort J, Chabrol O, Brisard D, Nguyen T, Le Cam A, et al. Oocyte-somatic 412 cells interactions, lessons from evolution. BMC Genomics. 2012;13(1).

413 26. Anil Deka, and J.D.Mahanta. Anatomy of ovary of Pati and Chara-Chemballi ducks (Anas 414 platyrhynchos domesticus) during laying periods. IOSR J Agric Vet Sci [Internet]. 415 2015;8(2):33-7. Available from: http://www.iosrjournals.org/iosr-javs/papers/vol8416 issue2/Version-1/I08213337.pdf

417 27. Kareem H, Alshammary A, Jabar AI, Abdul R, Nasser A. Geese ovary and oviduct from an 418 anatomical and histological point of view. Rjpbcs. 2017;8(6):207-19.

419 28. Da Silva-Buttkus P, Jayasooriya GS, Mora JM, Mobberley M, Ryder TA, Baithun M, et al. 420 Effect of cell shape and packing density on granulosa cell proliferation and formation of 421 multiple layers during early follicle development in the ovary. J Cell Sci. $422 \quad 2008 ; 121(23): 3890-900$.

423 29. Machado FZ, Bergamo LZ, Bizarro-Silva C, Morotti F, Silva-Santos KC, Seneda MM. Cell 424 proliferation in ovarian follicles from Bos taurus indicus females with different antral 
follicle count. Anim Reprod. 2017;14:1307-11.

426 30. Palermo R. Differential actions of FSH and LH during folliculogenesis. Reprod Biomed Online. 2007;15(3):326-37.

428 31. Regan SLP, Knight PG, Yovich JL, Leung Y, Arfuso F, Dharmarajan A. Involvement of 429

32. Parrott JA, Skinner MK. Kit ligand actions on ovarian stromal cells: Effects on theca cell recruitment and steroid production. Mol Reprod Dev. 2000;55(1):55-64.

33. Cui Y ming, Wang J, Hai-jun Z, Feng J, Wu S geng, Qi G hai. Effect of photoperiod on 435

34. Hernandez AG, Bahr JM. Role of FSH and epidermal growth factor (EGF) in the initiation of steroidogenesis in granulosa cells associated with follicular selection in chicken ovaries. Reproduction. 2003;125(5):683-691.

444 36. Hrabia A, Ha Y, Shimada K. Expression of estrogen receptor $\alpha \mathrm{mRNA}$ in theca and 445 
447 37. Zoheir KMA, Ahmed RG. Patterns of folliculogenesis in ducks following the administration 448 of a gonadotropin-releasing hormone $1(\mathrm{GnRH})$ analogue. J Genet Eng Biotechnol 449 [Internet]. 2012;10(1):93-9. Available from: http://dx.doi.org/10.1016/j.jgeb.2011.12.002

450

451

452

453

454

455

456

457

458

459

460

461

462

463

464 465

466

38. Szenci O, Takács E, Sulon J, Sousa NM de, Beckers JF. Evaluation of GnRH treatment 12 days after $\mathrm{AI}$ in the reproductive performance of dairy cows. Theriogenology. 2006;66(8):1811-5.

39. Yang YZ, Yao Y, Cao ZF, Gu TT, Xu Q, Chen GH. Histological characteristics of follicles and reproductive hormone secretion during ovarian follicle development in laying geese. Poult Sci. 2019;98(11):6063-70.

40. Johnson AL. Ovarian follicle selection and granulosa cell differentiation. Poult Sci. 2014;94(4):781-5.

41. Orisaka M, Tajima K, Tsang BK, Kotsuji F. Oocyte-granulosa-theca cell interactions during preantral follicular development. J Ovarian Res. 2009;2(1):9.

42. Rodler D. Histochemical detection of glycoconjugates in the inner perivitelline layer of Japanese quail (Coturnix japonica). J Vet Med Ser C Anat Histol Embryol. 2011;40(6):4419.

43. Sea. K. Anatomical atlas of poultry [M]. Beijing: China Agriculture Press, 2010. 2010.

44. Schmittgen TD, Livak KJ. Analyzing real-time PCR data by the comparative C(T) method. Nat Protoc. 2008;3(6):1101-8.

45. Gougeon A. Regulation of ovarian follicular development in primates: facts and hypotheses. 
Endocr Rev. 1996;17(2):121-55.

468

472 473

474

475

476

477 478

479

480

46. D'Haeseleer M. Localization and distribution of estrogen receptors and progesterone receptors in the bovine ovary in relation to the cell dynamics. 2006.

47. Hrabia A, Wilk M, Rzasa J. Expression of alpha and beta estrogen receptors in the chicken ovary. Folia Biol. 2008;56(3-4):187-91.

48. Leśniak-walentyn A, Hrabia A. Estrogen receptors mRNA expression in the prehierarchical ovarian follicles in the growing chicken after growth hormone administration. J Microbiol Biotech Food Sci. 2014;3(2):54-7.

49. Bédécarrats GY, Hanlon C. Effect of Lighting and Photoperiod on Chicken Egg Production and Quality. In: Egg Innovations and Strategies for Improvements. 2017. p. 65-75.

50. Yin ZZ, Dong XY, Cao HY, Mao HG, Ma YZ. Effects of rearing systems on reproductive hormones secretion and their receptors gene expression in Xianju chickens under summer conditions. Poult Sci. 2018;97(9):3092-6.

51. Rosenfeld C. Intraovarian actions of oestrogen. Reproduction. 2001;122(2):215-26.

52. Calatayud NE, Pask AJ, Shaw G, Richings NM, Osborn S, Renfree MB. Ontogeny of the oestrogen receptors ESR1 and ESR2 during gonadal development in the tammar wallaby, Macropus eugenii. Reproduction. 2010;139(3):599-611.

53. Saunders PTK, Millar MR, Williams K, Macpherson S, Harkiss D, Anderson RA, et al. Differential expression of estrogen receptor- $\alpha$ and $-\beta$ and androgen receptor in the ovaries of marmosets and humans. Biol Reprod. 2000;63(4):1098-105.

54. Pelletier G, El-Alfy M. Immunocytochemical localization of estrogen receptors $\alpha$ and $\beta$ in 
the human reproductive organs. J Clin Endocrinol Metab. 2000;85(12):4835-40.

489 55. Rosenfeld CS, Yuan X, Manikkam M, Calder MD, Garverick HA, Lubahn DB. Cloning, 490 sequencing, and localization of bovine estrogen receptor- $\beta$ within the ovarian follicle. Biol 491 Reprod. 1999;60(3):691-7.

492 56. Pelletier C, Labrie C, Labrie F. Localization of oestrogen receptor $\alpha$, oestrogen receptor $\beta$ 493 and androgen receptors in the rat reproductive organs. J Endocrinol. 2000;165(2):359-70.

494 57. Jansen HT, West C, Lehman MN, Padmanabhan V. Ovarian estrogen receptor- $\beta$ (er $\beta$ ) 495 regulation: I. Changes in ER $\beta$ messenger RNA expression prior to ovulation in the ewe. $496 \quad$ Biol Reprod. 2001;65(3):866-72.

497 58. Diaz FJ, Anthony K, Halfhill AN. Early avian follicular development is characterized by 498 changes in transcripts involved in steroidogenesis, paracrine signaling and transcription. 499 Mol Reprod Dev. 2011;78(33):212-23.

500

59. Chen Xiu Ping, Jiang Xun Ping DJT. Apoptosis of goose granulosa cells and its relationship 501 between reproductive hormones. Acta Vet Zootech Sin. 2006;37(10):982-6.

502 60. Braw-Tal R. The initiation of follicle growth: The oocyte or the somatic cells? Mol Cell $503 \quad$ Endocrinol. 2002;187(1-2):11-8.

504 61. Ghanem K, Johnson AL. Follicle dynamics and granulosa cell differentiation in the Turkey 505 hen ovary. Poult Sci. 2018;97(10):3755-61. 